\title{
Disabled Laborers And The Equal Employment Opportunity Commission's (EEOCs) Nightmare
}

\author{
C. Kenneth Meyer, Drake University, USA \\ Allen Zagoren, Drake University, USA \\ Kelsie Wolfe, MPA, Drake University, USA \\ Tristan Lynn, Iowa College Student Aid Commission, USA \\ Bill Moorman, Colorado State University - Pueblo, USA
}

\begin{abstract}
In 2012, EEOC v. Henry's Turkey Service was one of the largest disability settlements in American history. Henry's Turkey Service was ordered to pay \$240 million for paying mentally disabled workers with I.Q.s estimated in the 6070 range, 41 cents per hour and housing them in unsafe housing and health conditions (Hsieh, 2013). Over forty years, Henry's Turkey Service relocated hundreds of mentally disabled workers from Texas to Iowa where they were subjected to horrendous living conditions with unlawful, minimal pay-about $\$ 65.00$ per month, while they worked at a local turkey processing factory in West Liberty, Iowa. The actual case shows a pattern of violations of the Fair Labor Standards Act of 1938 and Americans with Disability Act, 1990. After a raid of the bright blue, florescent colored, century old school house in Atalissa, Iowa, these employers were brought to justice. This case study is about one of the largest EEOC settlements in the history of the United States; yet due to federal damage caps was cut to $\$ 1.6$ million for all of the men and their estates. The graphic account of the inhumane treatment and degradation of the labors presented in this study is not provided for gratuitous or salacious purposes; rather, it places into context what can occur when governmental regulations and laws go unheeded, unenforced and when authorities are apprised of wrongdoing possibilities stand idly by and in this case, do nothing for 35 years.
\end{abstract}

Keywords: Discrimination; Diversity; Americans with Disability Act (ADA, 1990); Disability; Equal Employment Opportunity Commission (EEOC); Fair Labor Standards Act (FLSA); Media Relations; Ethics; Civil Rights Act; 1964 (CRA, 1964); Human Resources Management; Elder Abuse

Recommended Courses: Workplace Diversity; Case Studies in Management; State and Local Government; Administrative Law; Management; Ethical Decision Making; Public Policy Analysis; Public Administration

\section{AN UNCOMMONLY SIMPLE INTRODUCTION}

$\mathscr{J}$ ames Neubauer and Kara Scott didn't think too much on helping out the neighboring schoolhouse that later would reveal, “...37 plus years of secrets, neglect, and deplorable actions.” (Kauffman, 2011). James and Kara lived in a mobile home situated next to the "bunkhouse"-a nickname given to the bright blue, florescent colored former school house that provided a home for 32 "disabled laborers." Subjected to various kinds of mistreatment and financial exploitation, it was alleged that Henry's Turkey Service (HTS) used punishment to ensure good behavior. Although complaints were filed with the Iowa Department of Human Services (IDHS) from sundry sources, including the mayor and other Atalissa city officials and co-workers, no action was taken. Also, in 1997, the state of Texas requested that IDHS investigate the poor treatment of the Atalissa workers and a social worker for DHS concluded that it "...seems to us these folks are Texas' responsibility" (Kaufmann, 2014). In 1997 the U.S. Department of Labor investigated both companies that disclosed wage and hour violations, but no penalties were 
imposed (Kaufman, 2014). Then in 2007, Paul Pettigrew, complained to IDHS about his brother's treatment in the bunkhouse, but the department did not investigate (Kaufman, 2014).

\section{Supervision and Conditions in the Bunkhouse}

The bunkhouse was overseen by Kenneth Henry, a Texan, who later relocated to Iowa and founded, Henry's Turkey Service. The idea of using "troubled" men who would otherwise be institutionalized as low cost labor was in place in Texas during the 1960s. A few years later, Henry would join in his widower's company, Hill Country Farms. Although the two were owned by the same people, they were independent companies, and as later investigation revealed, Henry's Turkey Service did not legally exist except as the payee for the wages of its employed laborers. As it was discovered, Henry's deducted as much as $\$ 1,000$ per month from the men's paychecks for room and board. As such, the firm acted as landlord, employer, and caregiver and pay for their laborer was based on the number of birds each man processed (Kauffman, 2009a).

The "disabled laborers" were intellectually disabled and were referred to as resident workers because their contract collectively administered their living and working arrangements. Under the FLSA, 1938, "certified employers" can pay a lesser wage to disabled workers "based on productivity" in comparison to non-disabled workers-although in the court proceedings, a comparison of relative productivity levels of the two groups of employees was not at issuealthough they handled about 20,000 turkeys, weighing 30 pounds each, every day that they worked in the plants (Barry, 2014). The company provided two adults that covered the nighttime hours for resident workers, although the two rarely provided any other assistance (Iowa Department of Workforce Development Division of Labor, 2011). James and Kara became aware of the abuse of disabled workers and the legalism associated with some of the working, housing and living conditions, which the laborers were subjected to, which eventually resulted in a large number of state and federal charges brought by the Equal Employment Opportunity Commission (EEOC) against Henry's Turkey Service. The discrimination and unfair treatment of these American citizens marked "...the largest verdict in EEOC history" (U.S. Equal Employment Opportunity Commission, 2013).

\section{After Many Complaints, the Bunkhouse is Raided}

On February 5, 2009, state and federal law officials raided the century-old school in Atalissa, Iowa (Hsieh, 2013). Mike Rohner, a Health Facilities Surveyor for the State of Iowa, met in 2009 with Andy Weeks- the son of Dru Neubauer and stepson of Randy Neubauer, the "Bunkhouse" property managers - to discuss potential violations in the bunkhouse and at Hill Country Farms. Later on, Andy Weeks testified that he provided assistance to the residents during daytime hours, while James and Kara provided limited, if any, assistance during the evening hours. Rohner investigated the bunkhouse over a week in February conducted a physical tour of the bunkhouse where he noted many violations, such as blocked fire exits which were locked; emergency exit lights that did not work; dirty bathroom, kitchen area, and shower floor; unattended medication for laborers and cockroaches in the kitchen. In addition, several of the rooms had a strong odor of urine. These and other violations are presented in Exhibit 1. In total, the Department of Public Safety Fire Marshal documented 59 violations and concerns in their comprehensive inspection, and then, the bunkhouse, based on fire danger, was deemed uninhabitable and closed (Iowa Department of Workforce Development Division of Labor, 2011).

Kyle Gosh, of the state's fire marshal's office, stated that it “....appeared that for seven years the building was heated only with electric space heaters because the boiler [didn't] work." This caused a fire hazard "...in light of the padlocked exit doors, blocked doorways, defective lighting, exposed wood construction and other fire code violations." Another witness addressed the inadequacy of the bunkhouse and said, "...the smell of urine was overwhelming and it would take your breath away. I don't even know how to begin to describe the number of cockroaches. It was to the point where you could hear them in the walls" (Kauffman, 2013a). Another told of cockroaches falling into the food that the men ate. 
Exhibit 1. Listing of Selected Violations Reported

\author{
Main fire alarm system had been disabled \\ Fire exits were blocked/padlocked shut \\ Water damage and dripping water from the ceiling in the former gym \\ Several emergency exit lights were not functional \\ The battery-powered emergency lighting system was dysfunctional
}

\title{
Violation Descriptions
}

Boiler was no longer functional

Space heaters used as the main source of heat

Space heaters were overloading the circuit and were powered by extension cords

Holes in the ceiling in the dining room and inside the main entry

A urine stained mattress was upright drying out and was moldy

Flaking paint was found in a very dirty bathroom

Mouse droppings were identified in food storage cupboards

Cockroaches were present

Worn surfaces on serving counters

Dirty and greasy kitchen floor

Dirty and greasy surfaces near the stove

Two large gas water heaters in the kitchen vented directly into the kitchen

Disassembled vents due to pilot lights going out

Cockroaches seen in the kitchen during meal preparation

Bathroom floor is dirty with strong odor of urine and flaking paint

\author{
Shower floor was very dirty with the accumulation of refuse \\ Bathroom stalls lacking doors or privacy curtains \\ Dining room table was cracked making disinfection difficult \\ Dining room ceiling was stained with a large hole above the table \\ Floors and walls were dirty and cracked \\ Medication for laborers was sitting out on the table unattended \\ Medications were on a board with a string used to separate medications per laborer \\ Medication board was dusty with a white powder due to lack of cleaning \\ No medication administration records maintained \\ Medication was locked
}

\section{What Did She Know and When Did She Know It?}

Investigation showed that Dru Neubauer knew about the building violations, but explained that the building wasn't always in a state of disrepair. When T.H. Johnson left the company three years ago, she indicated, cash flow for repairs were cut. Dru and Randy were told that enough money had been spent on the building and for financial reasons stop making repairs. In addition, the grocery budget for the bunkhouse was cut in half. Dru feared that if she reported the living conditions, the workers would not receive proper care. She also was aware that pay stubs were never provided for workers. She reported her fears to T.H. Johnson, but Randy's and her jobs were threatened if they reported the bunkhouse, and so they both kept quiet about their concerns until Rohner's investigation had been conducted. Over the next few years, the company known as Henry's Turkey Service was investigated (Iowa Department of Workforce Development Division of Labor, 2011).

From 2009 through 2011, the Iowa Workforce Development (IWFD) launched an investigation into the wage violations committed by Kenneth Henry, Jane Johnson, and Hill Country Farms. Over time, many county, state and federal agencies became affiliated with the neglect and abuses as shown in Exhibit 2. Agencies Involved in the Henry's Turkey Service v. Iowa Department of Workforce, Division of Labor Services. 
Exhibit 2. Agencies Involved in the Henry's Turkey Service v. IWD'S Division of Labor Services

\begin{tabular}{l}
\hline \multicolumn{1}{c}{ Selected Federal, State and Local governmental Agencies } \\
\hline State and federal law enforcement \\
\hline Iowa Department of Inspections and Appeals Division of Health Facilities \\
\hline Iowa Protection and Advocacy \\
\hline Iowa Department of Human Services \\
\hline Department of Public Safety Fire Marshal's Inspection Division \\
\hline The Department of Criminal Investigation (DCI) \\
\hline The Federal Bureau of Investigation \\
\hline Scott County Department of Human Services \\
\hline Lee County Department of Human Services \\
\hline Muscatine County Department of Human services \\
\hline Iowa Division of Labor \\
\hline
\end{tabular}

\section{Abuse of the "Boys" in the Bunkhouse: A Revealing View from the IDWD}

The Iowa Department of Workforce Development, Division of Labor, gave the following synopsis of the men who were abused in Atalissa, Iowa. The neglect, abuse, and financial exploitation is palpable in the department's findings:

The staff never had any formal training on how to work with and support persons with intellectual disabilities. The old school house they lived in was condemned in 2009 when DHS broke the case, due to the terrible conditions the men were living in. This included cockroaches, soiled beds, no air conditioning or open windows and the list goes on (Barry, 2014). Department of Public Safety Fire Marshal Inspection Division documented 59 total violations (Godfrey, 2011). Furthermore, the men were called names and physically abused. There are reports of the men being called 'retarded' and 'dumb.' According to Robert A. Canino, regional attorney for the U.S. Equal Employment Opportunity Commission, was quoted as saying, "These men suffered isolation and exploitation for many years while their employer cruelly consumed the fruits of their labor." There were reports of acts of physical abuse including hitting, kicking, at least one case of handcuffing, and forcing the disabled workers to carry heavy weights as punishment. The Henry's Turkey supervisors, also the workers' purported caretakers, were often dismissive of complaints of injuries or pain (Barry, 2014), (Bracken \& Woo, 2014). Not to mention, these men were not provided adequate medical care for 30 plus years. Their hands were disfigured from the grueling work they did at the turkey plant, their teeth were in bad condition and after being found in 2009 , one man had a broken knee and another man was found to have testicular problems after being kicked in the groin area (Godfrey, 2011).

Although Godfrey's report on the horrendous treatment and care of the 32 workers provides a heart rendering account on what transpired in the bunkhouse and where they worked (West Liberty Foods), other investigations revealed the pervasiveness of the inhuman treatment: "Caretakers allegedly kicked [Tommy] Johnson in the groin so often that a medical examination month later showed injuries to the man's testicles. Other workers were allegedly punished by being taken to a garage where they were forced to march around a pole while they hit, kicked, and screamed at by caretakers" (Kauffman, 2014). Additionally, the investigation indicated that "one worker wandered from the bunkhouse and froze to death. His body wasn't found until the following spring, tangled in a farm fence" (Kauffman, 2013b).

Contemporaneously, the bunkhouse investigation now reads like a novel that could be penned about a mythical "House of Horrors," in reality, and in Atalissa, Iowa, it became frightfully close to being unimaginable. For instance, a witness told about one of the workers abused by the pole routine "... wore leg races and was physically disabled" (Kauffman, 2013a). While the ritualistic punishment was meted out, a witness told of physical assaults and verbal taunts - men cursed at and subject to being called "retard" or called racial epithets (Witness: etc.). It was also alleged that some men were routinely kicked in the scrotum by one of the caretakers; another worker was handcuffed to the bed and sometimes denied the right to attend church services. Earlier, a caretaker was fired for allegedly having paid for sex with one of the men. In response, she stated that the caretakers would "...stuff towels into the mouth of one man to 
silence him; would lock another man in his room." They were, she said, treated like "indentured servants" (Kauffman, 2009c).

\section{Final disposition of the Case Study}

The three appellants were found guilty of 11,644 total wage violations by failure to pay a minimum wage; failure to provide wage statements to the workers; making improper wage deductions for room and board; and, for imposing improper wage deductions for "in-kind care." (Iowa Department of Workforce Development Division of Labor, 2011). For instance money was withheld from their Social Security earnings and from monthly incomes to pay for in-kind services, which, it turns out was used to buy goods from the Johnson family's general store (Godfrey, 2011). No criminal charges were filed against the defendants. These findings were filed and the men were moved to Exceptional Persons, Inc. in Waterloo, IA.

The 32 men and the EEOC went on to fight a bigger battle under the Americans with Disability Act of 1990 (U.S. Equal Employment Opportunity Commission, 2013) In the final analysis, IWFD recorded that there were 11,644 wage violations from April 1, 2007 through February 6, 2009, from failure to pay minimum wage per Iowa Code section 91D.1, failure to provide a "pay stub" per Iowa Code section 91A.6(4) and making one or more illegal deductions as defined by Iowa Code section 91A.5, and stated that the appropriate civil penalties for these violations against the appellants are $\$ 1,164,400.00$. They succinctly concluded: "Locked behind the doors of the "bunkhouse" ...were 37 plus years of secrets, neglect, and deplorable actions" (Godfred, 2011).

In contrast, the defendants believed that the "boys"- as they were referred to by the locals--were not mistreated and that they had been clever enough to "conn" the community. Even the sheriff of a local county did not believe there was abuse since the men "...had about every game, game table, yard games, etc., to play in their off hours both indoor and outdoor" (Barry, 2014). He further stated, "I don't believe there is any one of my staff that felt that these individuals were in anyway abused or mistreated" (Barry, 2014) The appellants, legal documents show, continued "...to argue that their blatant violations are not in fact violations and that they are not the employer" (Godfrey, 2011)

\section{The Settlement was not as Large as it Appeared at First Glance}

On May 1, 2013, the EEOC was awarded \$240 million for discrimination and severe abuse against persons with disabilities. As provided for under the ADA, it is "...unlawful to discriminate in employment against a qualified individual with a disability." Additionally, ADA “...outlaw's discrimination against individuals with disabilities in state and local government services, public accommodations, transportation and telecommunications." Several major or salient arguments were made by EEOC: "...that people with disabilities can be great employees, if given the opportunity to fairly compete and prove themselves (U.S. Equal Employment Opportunity Commission, 2013) and that people with disabilities have a right to live full and productive lives - to be treated with dignity. Last, EEOC argued that the types of disabilities the men had, "...made them particularly vulnerable and unaware of the extent to which their legal rights were being denied." The $\$ 240$ million was assessed by the court accordingly: $\$ 5.5$ million in compensatory damages for each of the 32 men who worked for Henry's between 2007 and 2009; and, \$2 million each as punitive damages due to "Henry's acting with malice or reckless indifference." In the closing argument, the EEOC attorney asked the jurors to provide the men compensation for "... their broken hearts, broken spirits, shattered dreams and, ultimately their broken lives" (Kauffman, 20I3b). In the final disposition of the award, the settlement was drastically reduced to $\$ 1.6$ million because of federal damage caps (Associated Press, 2014).

The men after being rescued in 2009 were moved to a nonprofit agency that specialized in supporting persons with intellectual disabilities and the appellants, Henry and Johnson died in 2008.

\section{Wrap-Up: Have we ever heard "Never Again?"}

Perhaps the seeds of conflicts of interest and potential wrongdoing revealed in this case study were put into motion when several labor brokers, Kenneth J. Henry and Thurman "T.H." Johnson, both from Texas, were paid \$1,050 per 
candidate by the Texas Rehabilitation Commission to provide job training for "young, mentally retarded men" (Kauffman, 2009b). Subsequently, they were then "...sent to labor camps in at least six states, working at turkeyinsemination farms and processing plants" [Kauffman, 2009b). The widow of the now deceased Johnson, made these summary statements: "At this point, I'd just rather not explain anything. We tried to take care of those boys the best we could" (Kauffman, 2009b).

The governor of Iowa at the time, Chet Culver stated "...that Henry's Turkey Service was guided more by "financial self-interest" than by compassion and concern for its workers' welfare" (Kauffman, 2009e). The governor also stated that "...every level of government bureaucracy failed these men" (Kauffman, 2009d). The failure of government went on for 35 years - from 1974 - and he concluded "...I will do all I can to make sure it will never happen in the future as long as I am governor” (Kauffman, 2009d).

In an opinion piece, Kurt Ullrich summed up the situation at the bunkhouse very succinctly: He wrote that "The poor, sad, disabled men laboring for Henry's Turkey Service were each assigned a number, much like those assigned to prisoners in our vast correctional system" (Ullrich, 2013). He stated that the "troubled, helpless" men were housed in a "...decrepit building in a town where locals pretended all was well (Ullrich, 2013). On their persons, Ullrich stated, they had no identification cards and no way to open a bank account, and "...no way to prove who they are" (Ullrich, 2013). Never being too old to retire, the men who were paid "as little as 40 cents an hour" for their labor at West Liberty Foods, and were moved to an egg farm..."when they became too old to work at West Liberty Foods" (Kauffman, 2009f). Placed in a retirement context, a sister of one of the men reported to the Department of Health Services Hotline that her brother had only $\$ 80.00$ to his name upon retirement after dong manual work for HTS for more than thirty years (Barry, 2014).

Of course, given the statements in this case study about the inhumane treatment the men received in the bunkhouse and at work, such as infrequent and insufficient rest breaks, so the men soiled themselves, it raises questions about the impact of total institutionalization conditions and behavior reminiscent of the horrible atrocities that took place in an earlier time. In summation, the value of these men was in the work they performed, not in the dignity, respect, and value of the lives they were compelled by their mental disabilities to lead, and as it turned out, and to do so anonymously.

\section{QUESTIONS AND INSTRUCTIONS:}

1. Describe the ethical dilemma of James Neubauer and Kara Scott? What would you have done differently? Explain.

2. What is the formal process for filing a complaint with the U.S. Equal Employment Opportunity Commission? Are different processes used for different types of discrimination or for specific occupations? Explain.

3. Why do you think Kenneth Henry decided to utilize "disabled laborers" to work in his factory? Please list and explain at least three potential benefits and three potential disadvantages of hiring "disabled laborers." Please be specific.

4. What legal wage deductions can be made by employers in your state? Explain.

5. Should there be a limit to the amount of penalties one company can be fined for and required to pay for compensatory and/or punitive damages? Or, alternative, did the Iowa jury have the assessment correct? Why or why not?

6. Henry's Turkey Services believed that they were doing a favor for the disabled persons since they were given a job, paid for their labor, and that the workers became independent from the government Please analyze the pros and cons of this affirmation.

7. Do you believe that the case can be made that this case is illustrative of the administration of evil? If so, why? If not, why not. Please elaborate your position. 
Disabled Laborers and the Equal Employment Opportunity Commission's Nightmare

Name:

Case Log and Administrative Journal Entry

This case analysis and learning assessment may be submitted for either instructor or peer assessment

\section{Case Analysis:}

Major case concepts and theories identified:

What is the relevance of the concepts, theories, ideas and techniques presented in the case to that of public or private management?

Facts - what do we know for sure about the case? Please list.

Who is involved in the case (people, departments, agencies, units, etc.)? Were the problems of an "intra/interagency" nature? Be specific.

Are there any rules, laws, regulations or standard operating procedures identified in the case study that might limit decision-making? If so, what are they?

Are there any clues presented in the case as to the major actor's interests, needs, motivations and personalities? If so, please list them.

\section{Learning Assessment:}

What do the administrative theories presented in this case mean to you as an administrator or manager? 
How can this learning be put to use outside the classroom? Are there any problems you envision during the implementation phase?

Several possible courses of action were identified during the class discussion. Which action was considered to be most practical by the group? Which was deemed most feasible? Based on your personal experience, did the group reach a conclusion that was desirable, feasible, and practical? Please explain why or why not.

Did the group reach a decision that would solve the problem on a short-term or long-term basis? Please explain.

What could you have done to receive more learning value from this case?

Source: Case Log and Administrative Journal Entry reprinted with permission, Millennium HRM Press, Inc.

\section{AUTHOR BIOGRAPHIES}

C. Kenneth Meyer is Thomas F. Sheehan Distinguished Professor of Public Administration, Drake University. He previously held teaching positions at Winona State University, State University of New York, University of South Dakota and the University of Oklahoma, Norman, Oklahoma. He has nearly 300 published case studies that appear in numerous venues. He is the co-author of Managing People as Assets; Human Relations in Action; Managing America's Organizations; and Managing Public Service Organization; Conducting the People's Business; and Organizational Change. His newest books are entitled Nonprofit Management and Leadership Case Studies (2014), Solving Public Management Problems: A Case Study Approach (2015), Understanding Nonprofit Organizations (2016), The Craft of Public Administration, 11/e (2016) and Experiencing State and Local Government Management (forthcoming, 2017). E-mail: kenneth.meyer@drake.edu

Allen J. Zagoren is Associate Professor of Public Administration and Chairperson of the Department of Public Administration at Drake University, College of Business and Public Administration. His undergraduate degree is form Hofstra University and he holds a Master of Public Administration degree, Drake University, and the Doctor of Osteopathic Medicine from Philadelphia College of Osteopathic Medicine. He has published over 60 articles and book chapters in clinical surgical practice and public administration, and is co-author of Solving Public Management Problems; A Case Sturdy Approach, 2015. E-mail: Allen.Zagoren@Drake.edu.

Kelsie Wolfe earned an undergraduate degree in communications and public relations from the University of Northern Iowa, and a Master of Public Administration degree from Drake University. She has served in a number of human resource management positions in the private and public service sectors.

Tristan D. Lynn received a Baccalaureate degree from the American Institute of Business and a Master of Public Administration degree from Drake University. He is presently employed as a Student Financial aid Program Specialist at the Iowa College Student Aid Commission, Des Moines, Iowa. E-mail: tristan.d.lynn@gmail.com 
Bill Moorman received his undergraduate degree in Exercise Science, Health Promotion and Recreation from Colorado State University - Pueblo, and his Master of Public Administration degree from Drake University. Presently, he is the Coordinator of Intramural and Club sports, Colorado State University - Pueblo, Colorado. E-mail: bill.moorman@csupueblo.edu

\section{REFERENCES}

Associated Press (2014, August 3). Disabled workers' bunkhouse torn down. The Des Moines Sunday Register.

Barry, D. (2014, March 09). The "boys" in the bunkhouse: Toil, abuse, and endurance in the heartland. The New York Times. Retrieved from http://www.nytimes.com/interactive/2014/03/09/us/the-boys-in-the-bunkhouse.html?_r=0

Bracken, K., and John Woo. (2014, July 30). From Schoolhouse to symbol of servitude, to dust. The New York Times, A12.

Godfrey, C. Iowa Department of Workforce Development Division of Labor, (2011). Final agency decision (IWD No. CP-003-09 DIA No. 09IWD030). Iowa:

Hsieh, S. (2013, May 6). \$240M to Disabled Workers Abused in Company's 'House of Horrors'. Retrieved November 26, 2013, from Lawyers.com: http://blogs.lawyers.com/2013/05/240m-to-mentally-disabled-workers-abused/

Iowa Department of Workforce Development, Division of Labor Services. (2011). Henry's Turkey Service v. Division of Labor Services. Des Moines: IWD No. CP-003-09; DIA No. 09IWD030.

http://www.desmoinesregister.com/article/20140309/NEWS14/303090023/Register-Investigation-Millions-fines-will-Henry-sTurkey-Service-ever-pay-

Kauffman, C. (2009a, February 7). Potential issues in Henry's turkey case. The Des Moines Register.

Kauffman, C. (2009b, February 14). 22 brokers got thousands for using men. The Des Moines Register.

Kauffman, C. (2009c, February 25). Abuse, sex for pay alleged at bunkhouse in Atalissa. The Des Moines Register

Kauffman, C. (2009d, February 26). Culver on Atalissa: 'Every level of government failed." The Des Moines Register

Kauffman, C. (2009e, March 6). Henry's executives earned moderate salaries, data shows. The Des Moines Register.

Kauffman, C. (2009f, October 31). State sends prosecutor its findings on Atalissa. The Des Moines Register.

Kauffman, C. (2011, May 8). \$1.1 million fine for Henry's Turkey Service is reinstated. Retrieved November 2013, from The Des Moines Register: http://www.desmoinesregister.com/article/20110309/NEWS10/103090345/

Kauffman, C. (2013a, April 25). Witness: Disabled workers physically abuse. The Des Moines Register.

Kauffman, C. (2013b, May 1). Jury: \$240 million for Atalissa workers. The Des Moines Register

Kauffman, C. (2014, March 7). Register investigation: Millions in fines, but will Henry's Turkey Service ever pay. The Des Moines Register. Retrieved from

Ullrich, Kurt. (2013, May 4). Iowa view: Our fellow humans deserve better from us. The Des Moines Register.

U.S. Equal Employment Opportunity Commission. (2013, May 1). Jury Awards \$240 Million for Long-Term Abuse of Workers with Intellectual Disabilities. Retrieved November 2013, from U.S. Equal Employment Opportunity Commission:

\section{Suggested References on Research on EEOC laws and policies, mandatory reporting, adult and elderly abuse, aging,} ADA and FSLA

Jury Awards \$240 Million for Long-Term Abuse of Workers with Intellectual Disabilities (http://www.eeoc.gov/eeoc/newsroom/release/5-1-13b.cfm)

Dependent Adult Abuse Rules Training, Iowa Department of Inspection and Appeals (www.state.ia.us/government/dia/ICN Training PPT.ppt)

Welcome to Mandatory Reporter: Child and Dependent Adult Abuse Training, AEA 11 (www.aea11.k12.ia.us/prodev/mandatory/mand/)

Dependent Adult Abuse Resources, Iowa Department of Human Services (www.dhs.state.ia.us/Consumers/Safety and Protection/Abuse Reporting/DependentAdultAbuse.html)

Iowa Department of Human Services, Dependent Adult Abuse: A Guide for Mandatory Reporters (www.dhs.state.ia.us/policyanalysis/PolicyManualPages/Manual Documents/Master/comm118.pdf)

Quarterly Dependent Adult Abuse Report, Iowa Department of Human Services (http://publications.iowa.gov/)

Frequently Asked Questions, Iowa Department on Aging (www.aging.iowa.gov/faq/elderrights.html)

National Center on Elder Abuse, United States Administration on Aging (www.ncea.aoa.gov)

US Department of Labor, Fair Labor Standards Act (FLSA) (www.dol.gov/dol/topic/wages/subminimumwage.htm) 
NOTES 